\title{
Response of Soft-Bottom Benthos to Annual Catastrophic Disturbance in a South Florida Estuary*
}

\author{
S. L. Santos** and J. L. Simon \\ Department of Biology, University of South Florida, Tampa, Florida 33620, USA
}

\begin{abstract}
A portion of Hillsborough Bay (Tampa, Florida, USA), part of the Tampa Bay estuary, undergoes annual summer defaunation, presumably due to hypoxia. Dissolved oxygen levels are very low $\left(<1.0 \mathrm{mg} \mathrm{l}^{-1}\right)$ at the times of the defaunations. In the ensuing period between defaunations, recolonization occurs. Monthly samples for 42 consecutive months were collected by SCUBA-diver-operated, hand-held PVC cores and screened through a $0.5 \mathrm{~mm}$ sieve. Eight species, Mysella planulata, Ampelisca abdita, Streblospio benedicti, Grandidierella bonnieroides, Mulinia lateralis, Mediomastus californiensis, Cyclaspis $\mathrm{sp}$. and Nereis succinea were numerically dominant, accounting for more than $95 \%$ of the total density during the entire period. These 8 species are all classified as $r$-strategists and utilize several dispersal mechanisms to attain large populations rapidly. Circumstantial evidence is presented which indicates that Ampelisca abdita, although classified as an $r$-strategist, may be an effective interference competitor
\end{abstract}

\section{INTRODUCTION}

Recolonization patterns of marine soft-bottom benthos following disturbance have been examined from the viewpoint of community establishment (Brunswig et al., 1976; Dauer and Simon, 1976; Simon and Dauer, 1977; McCall, 1977; Santos and Simon, 1980), succession (Bagge, 1969; Leppakowski, 1969; Pearson, 1975; Rosenberg, 1973; 1974, 1976, 1977; Pearson and Rosenberg, 1978; Santos and Bloom, in prep.), and stability (Peterson, 1975; Conner, 1977; Gray 1977; Santos and Bloom, in prep.). In most instances however, the scope of the investigations has followed isolated disturbances and moreover, the severity of the disturbances has not approached catastrophic magnitudes (catastrophic is defined as the level of disturbance that causes extirpation of the organisms from the area investigated).

Because most catastrophic events are aperiodic, at least on an ecological time frame, and hence unpre-

\footnotetext{
- A portion of a dissertation (SLS) submitted in partial fulfillment of the Ph. D. degree, Department of Biology, University of South Florida, Tampa, Florida, USA.

- Present address: Faculty of Natural Sciences and Mathematics, Stockton State College, Pomona, N. J. 08240, USA
}

(c) by Inter-Research dictable, investigations on their effects have been of a limited or 'one shot' nature, and thus unrepeatable. A few studies in estuarine systems (Tenore, 1972; Watling, 1975; Holland et al., 1977) noted annual catastrophic cycles, but because these were not the focal point of the studies, they were not treated in detail. Yet areas that undergo periodic catastrophic disturbance (providing the frequency of the disturbance is low enough to allow growth and reproduction of the colonizing organisms) lend themselves to the examination of such ephemeral community parameters as succession and stability and also of adaptive strategies of the colonizing species. In this paper we describe the dynamics of the numerically dominant infauna in response to annual catastrophic disturbance in a South Florida estuary

\section{METHODS AND MATERIALS}

The study site (Fig. 1) is located about $50 \mathrm{~m}$ ESE from the Ballast Point pier on the western side of Hillsborough Bay, Tampa (Florida, USA) at $27^{\circ} 53^{\prime} 15^{\prime \prime} \mathrm{N}$ and $82^{\circ} 28^{\prime} 35^{\prime \prime} \mathrm{W}$. Depth ranges from $4-5 \mathrm{~m}$, depending on tidal conditions. Tidal movement is slight, $\sim 0.5$ knots. Sediments are composed mostly of fine particles (mean percent of silt/clay $=10.34$ ). 
During the period February 1975 to July 1978 . monthly samples (with a single exception) were collected with SCUBA-diver-operated, hand-held PVC cores (inside diameter $=7.62 \mathrm{~cm}$, surface area $=$ $45.60 \mathrm{~cm}^{2}$ ) to a depth of $15 \mathrm{~cm}$. Sixteen cores were taken initially; species saturation curves (Holme, 1953) were generated and drawn by the computer program SPAREA (Bloom et al., 1977). As each of the curve generations demonstrated that the asymptote was reached by the ninth core, 10 cores were taken to insure an adequate sample size at subsequent collections. All samples were sieved through a $0.5 \mathrm{~mm}$ mesh screen. The portion retained was narcotized in a

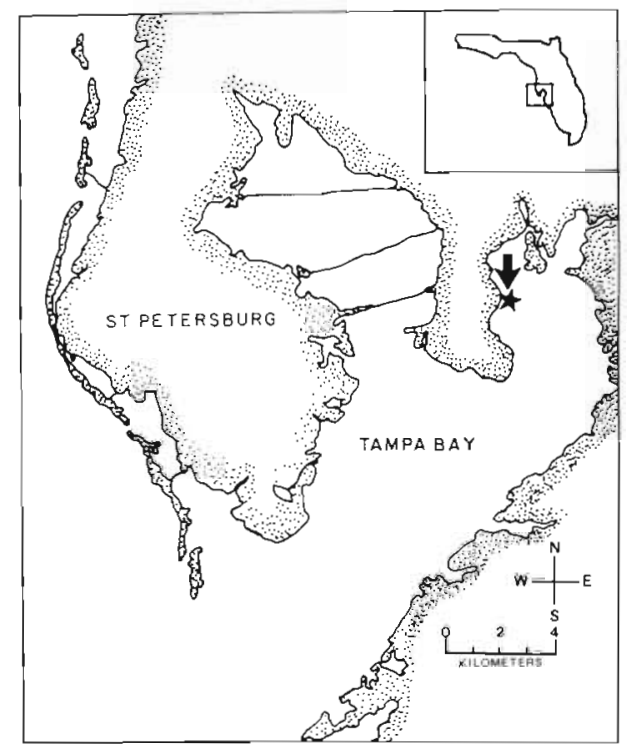

Fig. 1. Location of study area in Hillsborough Bay, Tampa, Florida, USA. Arrow denotes sample site

$0.15 \%$ solution of propylene phenoxetol (McKay and Hartzband, 1970) and fixed in 10\% formalin to which rose bengal had been added $\left(100 \mathrm{mg} \mathrm{I}^{-1}\right)$ (Mason and Yevich, 1967). All benthic macrofauna were sorted from the sediment, identified to the lowest practical taxon and enumerated. Faunal counts from each core were processed through the computer program DATPUN (Bloom et al., 1977) to obtain density values on a per-square-meter basis.

Monthly biomass was determined by the ash-free dry weight method (Crisp, 1971; Paine, 1971); specimes from all cores were pooled before processing. All specimens were dried at $60^{\circ} \mathrm{C}$ for at least $24 \mathrm{~h}$, then ashed in a muffle furnace at $550^{\circ} \mathrm{C}$ for $4 \mathrm{~h}$ and brought to constant weight. Biomass was calculated as the difference in weight before and after ignition.

Sediment samples were taken monthly, beginning July 1977, to determine particle size distribution and total organic content. Samples were wet-sieved through a Wentworth series of screens and dried at $60^{\circ} \mathrm{C}$. After bringing to constant weight, each fraction was weighed and cumulative percentages in phi units plotted (Krumbein, 1936). Mean phi and sorting coefficients were determined by the computer program SEDANA (Bloom et al., 1977) according to the formulae of Inman (1952). Total sediment organic carbon was also determined by the ash-free dry weight method (Byers et al., 1978). Differences in monthly sediments were tested for by a randomized complete block analysis of variance (rcbANOVA), where times (monthly samples) were considered treatments and sorting coefficient, mean phi and percent silt/clay values were considered blocks; a probability level of $\alpha=$ 0.05 was used.

All computer programs were written in FORTRAN IV and run on an IBM 370 computer at the University of South Florida Computer Research Center.

Temperature, dissolved oxygen and salinity measurements were made monthly by the Hillsborough County Environmental Protection Commission. All measurements were made in the field with a Hydrolab Surveyor, Model 6-D, that had been calibrated to standards before each use.

\section{RESULTS}

Temperatures ranged from $9^{\circ}-31^{\circ} \mathrm{C}$, dissolved oxygen from $0.4-9.6 \mathrm{mg} \mathrm{l}^{-1}$ and salinity from $7-30 \%$ (Fig. $2)$. The values corresponding to the defaunation periods are given in Table 1 . Analysis of variance of mean phi, sorting coefficient and percent silt/clay values (Table 2) showed no significant differences between months.

A total of 80 species was present during the study period (see Appendix). The polychaetes were the dominant taxon, accounting for $33 \%$ of the total species composition followed by the amphipods and bivalves, respectively (Table 3). The number of species, total density $\left(\# \mathrm{~m}^{-2}\right.$ ) and biomass ( $\mathrm{g}$ dry weight $\mathrm{m}^{-2}$ ) ranged fron $0-29,0-216,577$ and $0-27$, respectively (Fig. 3). Annual cycles following the defaunations were similar in 1975 and 1976, and characterized by: a few months to recover, rapid rise to high values, an abrupt crash to zero followed by a few months of recovery and return to high values. In 1977 the pattern differed slightly. The required time to attain peak values was about the same but the crash was gradual, requiring $>2$ months (Fig. $3 \mathrm{~B}$ ). In all three cycles recolonization was apparent within 1 month following the defaunation.

Eight species cumulatively accounted for $95.69 \%$ of the total density during the entire study (Table 4); these species will be referred to as core species. With 


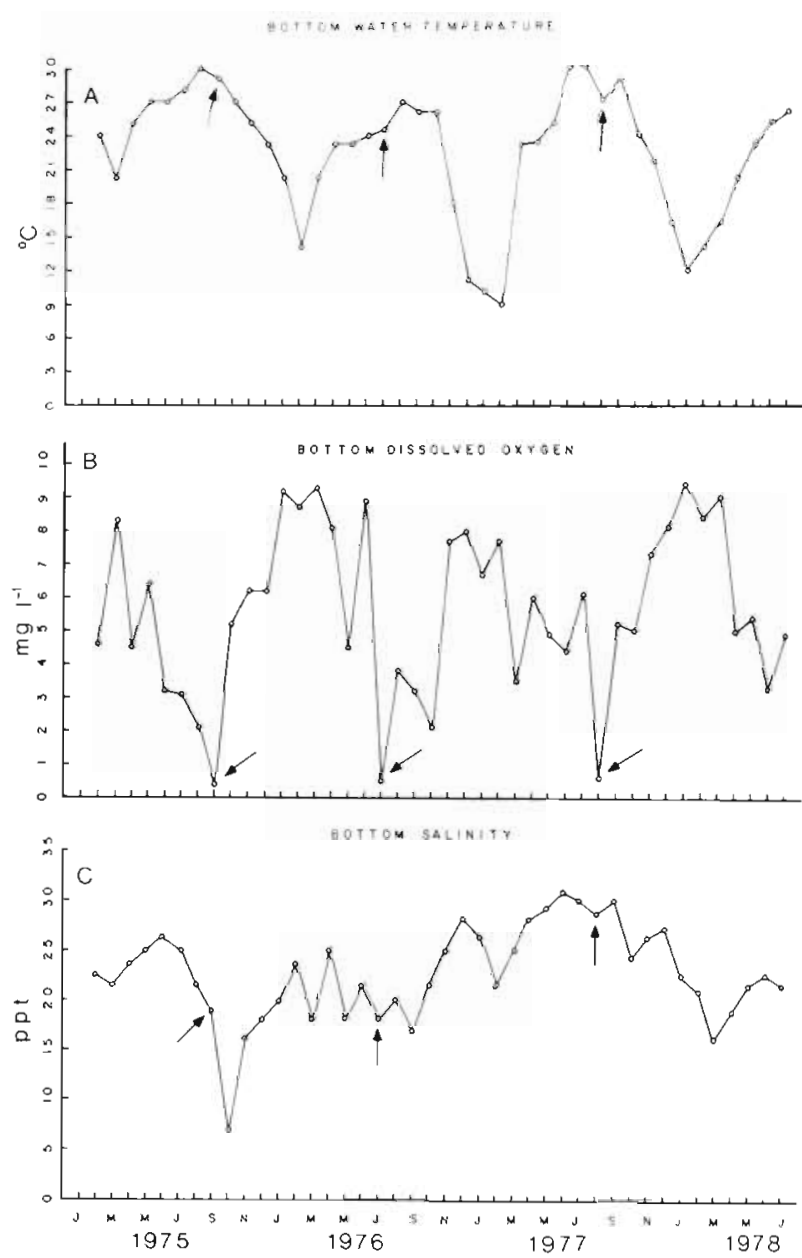

Fig. 2. Environmental parameter measurements in Hillsborough Bay during study period. Arrows indicate periods of defaunations

the exception of the first or second sampling periods immediately following a die-off (the third after the 1976 die-off), some members of the core group were always dominant at each sampling period (Table 5). Densities of these 8 individual species throughout the study are presented in Figure 4. Their occurrences are summarized below.

Mysella planulata (Stimpson 1851) - Mysella (Fig. dominant species for the first 7 months of the study (Table 5). After the 1975 die-off, it reappeared within 4 months and attained a density of $72,000 \mathrm{~m}^{-2}$ just before the 1976 die-off. Thereafter it again became dominant for a few months, disappeared for 2 months and was on the increase when the 1977 die-off occurred; densities were always $<2000 \mathrm{~m}^{-2}$. After the 1977 die-off, it never occurred at densities high enough to be included in the top five rankings; densities were maximally from 1000 to $4000 \mathrm{~m}^{-2}$.
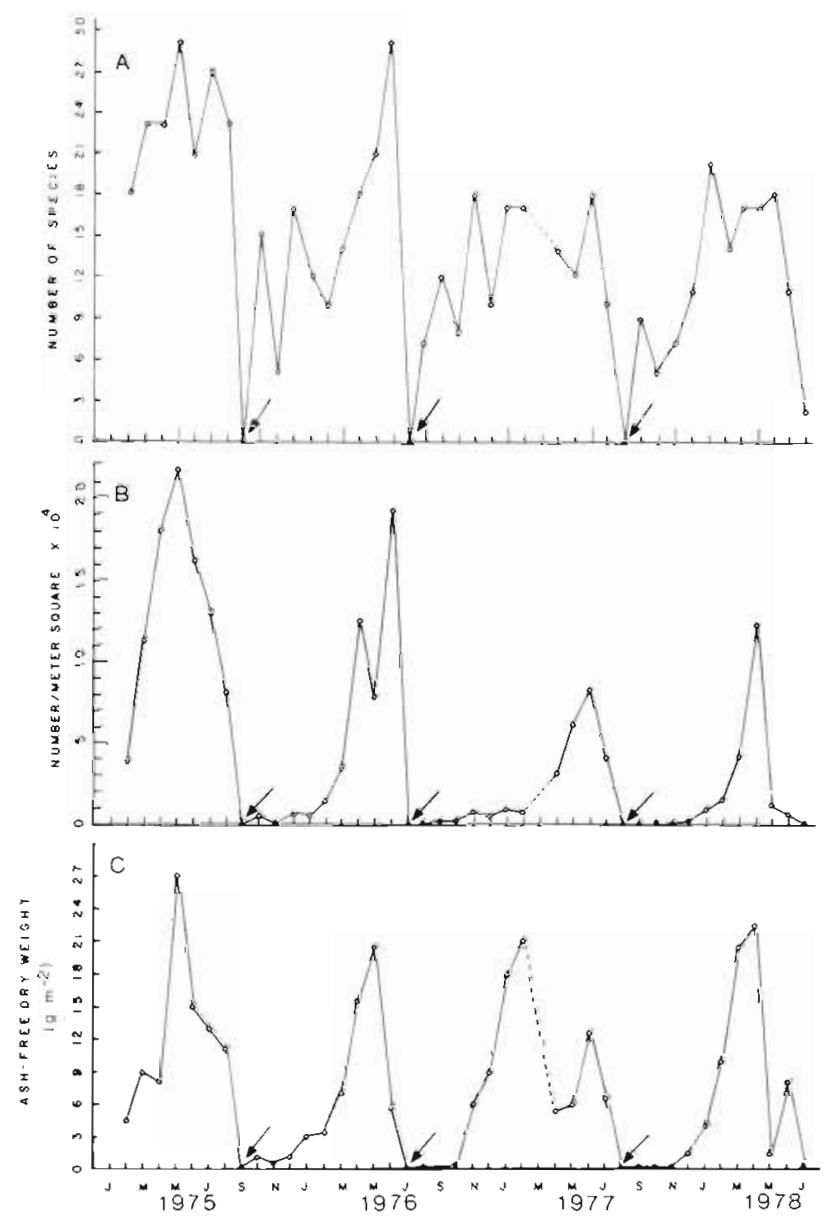

Fig. 3. Total faunal response in Hillsborough Bay during study period. A: Number of species, B: total density (\# $\mathrm{m}^{-2}$ ); $\mathrm{C}$ : total biomass ( $\mathrm{g}$ dry $\mathrm{wt} . \mathrm{m}^{-2}$ ). Arrows indicate periods of defaunations; broken lines indicate interpolated data

Table 1 Bottom water: environmental parameter values during defaunation periods

\begin{tabular}{|lrcc|}
\hline \multicolumn{1}{c}{ Parameter } & 1975 & 1976 & 1977 \\
\hline Temperature $\left({ }^{\circ} \mathrm{C}\right)$ & 29.0 & 24 & 27 \\
Dissolved oxygen $\left(\mathrm{mg} \mathrm{l}^{-1}\right)$ & 0.4 & 0.5 & 0.6 \\
Salinity (\%o) & 19.0 & 18.0 & 28.0 \\
\hline
\end{tabular}

Ampelisca abdita Mills 1964 - Ampelisca (Fig. 4B) is a tube-dwelling ampeliscid amphipod that occurred in very high densities during the first 2 years of the study (to $110,000 \mathrm{~m}^{-2}$ ). After the 1975 die-off, it reappeared within 2 months and by the sixth month attained top rank (Table 5). It reappeared 8 months after the 1976 die-off and again increased rapidly. It was top ranked for 2 months until the 1977 die-off. Subsequently it was virtually absent.

Streblospio benedicti Webster 1879 - Streblospio 
Table 2. Mean phi, sorting coefficients and percent silt/clay during period July $1977-J u l y ~ 1978$

\begin{tabular}{|lccr|}
\hline \multicolumn{1}{|c}{ Time } & $\begin{array}{c}\text { Mean } \\
\text { phi }\end{array}$ & $\begin{array}{c}\text { Sorting } \\
\text { coefficient }\end{array}$ & $\begin{array}{c}\text { Percent } \\
\text { silt/clay }\end{array}$ \\
\hline July 1977 & 1.67 & 1.04 & 7.12 \\
August 1977 & 1.59 & 1.02 & 9.52 \\
September 1977 & 1.55 & 1.28 & 11.14 \\
October 1977 & 2.30 & 1.09 & 12.54 \\
November 1977 & 2.58 & 1.24 & 13.16 \\
December 1977 & 2.14 & 0.86 & 6.50 \\
January 1978 & 2.54 & 0.99 & 11.33 \\
February 1978 & 1.77 & 0.96 & 9.95 \\
March 1978 & 1.75 & 1.06 & 6.95 \\
April 1978 & 1.72 & 0.86 & 7.52 \\
May 1978 & 2.18 & 0.87 & 11.34 \\
June 1978 & 2.03 & 1.24 & 13.33 \\
July 1978 & 2.40 & 1.14 & 14.08 \\
Annual Mean & 2.01 & 1.05 & 10.34 \\
\hline
\end{tabular}

(Fig. 4C), a small tube-dwelling spionid polychaete, was included in the top five rankings only three times before the 1976 die-off, and after the 1976 die-off, densities increased only slightly. However, after the 1977 die-off, it attained densities of up to $98,000 \mathrm{~m}^{-2}$. Grandidierella bonnieroides Stephenson 1949 Grandidierella (Fig. 4D) is an aorid amphipod that cooccurred with Ampelisca in high densities (to $96,000 \mathrm{~m}^{-2}$ ) during the first 7 months of the study. After the 1975 die-off, it took 8 months to reoccur. Since the 1976 die-off, it was not present in appreciable numbers $\left(<40 \mathrm{~m}^{-2}\right)$.
Table 3. Species composition of the benthic macroinvertebrate infauna of Hillsborough Bay, Florida, February 1975 to July 1978

\begin{tabular}{|lr|}
\hline \multicolumn{1}{|c}{ Taxon } & Percent composition \\
\hline Cnidaria & 2.50 \\
Platyhelminthes & 1.25 \\
Rhynchocoela & 1.25 \\
Polychaeta & 33.75 \\
Oligochaete & 1.25 \\
Pelycepoda & 15.00 \\
Gastropoda & 11.25 \\
Amphipoda & 16.25 \\
Isopoda & 2.50 \\
Mysidacea & 3.75 \\
Cumacea & 2.50 \\
Decapoda & 6.25 \\
Phoronida & 1.25 \\
Cephalocordata & 1.25 \\
Total & $100 \%$ \\
\hline
\end{tabular}

Mulinia lateralis (Say 1822) - Mulinia (Fig. 4E), a mactrid bivalve, occurred sparsely $\left(<400 \mathrm{~m}^{-2}\right)$ prior to the 1975 die-off. The third month after the die-off, it reached top rank and remained in the upper five until the 1976 die-off (Table 5). It took 4 months for Mulinia to regain ranking in the top five where it remained until the 1977 die-off. Four months later, it reappeared and remained constant, but at reduced numbers, until the 1978 die-off.

Mediomastus californiensis Hartman 1944 - Mediomastus (Fig. 4F), a small capitellid polychaete, was not present in the study area until after the 1977 die-off. It
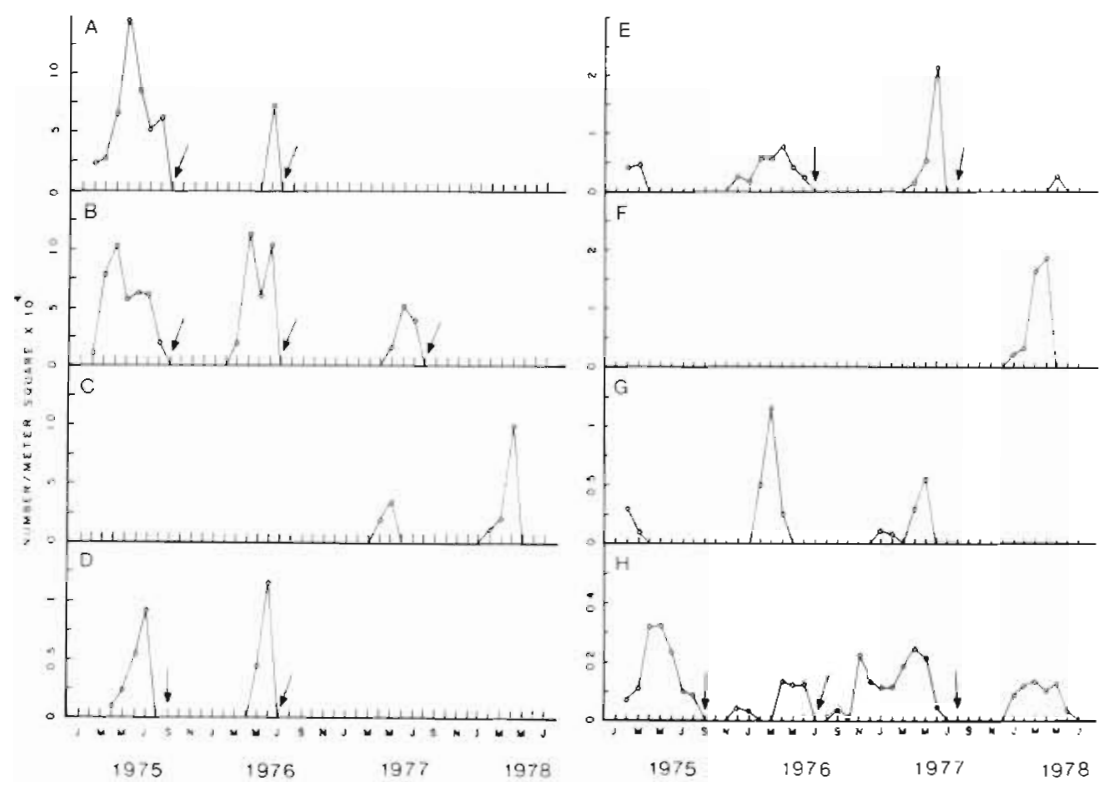

Fig. 4. Response of dominant species in Hillsborough Bay during study period. A: Mysella planulata; B: Ampelisca abdita; C: Streblospio benedicti; D: Grandidierella bonnieroides; E: Mulinia lateralis; F: Mediomastus californiensis; G: Cyclaspis sp.; 
Table 4. Density, percent composition and cumulative percent of the 8 numerically dominant species of benthic macroinvertebrate infauna in Hillsborough Bay, February 1975 to July 1978

\begin{tabular}{|lrrr|}
\hline \multicolumn{1}{|c}{ Species } & $\begin{array}{c}\sum \text { Density } \\
\left(\# \mathrm{~m}^{-2}\right)\end{array}$ & $\begin{array}{c}\text { Percent } \\
\text { Cumula- } \\
\text { tive } \\
\text { percent }\end{array}$ \\
\hline Ampelisca abdita & 786,217 & 42.93 & 42.93 \\
Mysella planulata & 549,982 & 30.03 & 72.95 \\
Streblospio benedicti & 198,670 & 10.85 & 83.80 \\
Mulinia lateralis & 74,022 & 4.04 & 87.84 \\
Mediomastus californiensis & 39,610 & 2.16 & 90.01 \\
Cyclaspis sp. & 35,330 & 1.93 & 91.94 \\
Nereis succinea & 35,230 & 1.92 & 93.86 \\
Grandidierella bonnieroides & 33,600 & 1.84 & 95.69 \\
\hline
\end{tabular}

became dominant after 4 months and remained so for 5 months, after which it virtually disappeared.

Cyclaspis sp. - Cyclaspis (Fig. 4G) is a small bodotriid cumacean. High densities $\left(11,000 \mathrm{~m}^{-2}\right)$ were not attained until 1976. After 4 months it disappeared and did not reappear until the middle of 1977 . Cyclaspis was present in the top five rankings for only 1 month after the 1977 die-off.

Nereis succinea Frey and Leuckart 1847 - Nereis (Fig. $4 \mathrm{H})$, a nereid polychaete, showed little variation in maximum density throughout the study (1000 to $3000 \mathrm{~m}^{-2}$ ). The reason for the change of rankings in Table 5 is attributable to the changes in densities of other species rather than large fluctuations in the density of Nereis.

\section{DISCUSSION AND CONCLUSIONS}

The actual causative agent of the defaunation is unknown; however, the extremely low dissolved oxygen levels which coincided with the actual die-off appear to be the prime suspect. Because the bottom of the study area is impossible to define at times due to its flocculent nature, the measurements were probably made above the actual sediment/water interface and are in all likelihood overestimates of conditions at the bottom.

Because the environmental parameters varied widely, even to catastrophic magnitudes, the study area can be regarded as structured by physical rather than biological forces (sensu Sanders, 1969). Although no significant differences in sedimentary parameters existed among the sampling periods, it is always possible that subtle changes in the structure of the sediment may affect settling larval organisms. For example, changes in silt/clay content may alter the dominant trophic type of the community (Sanders, 1958).

Because of the strong influence of physical factors,

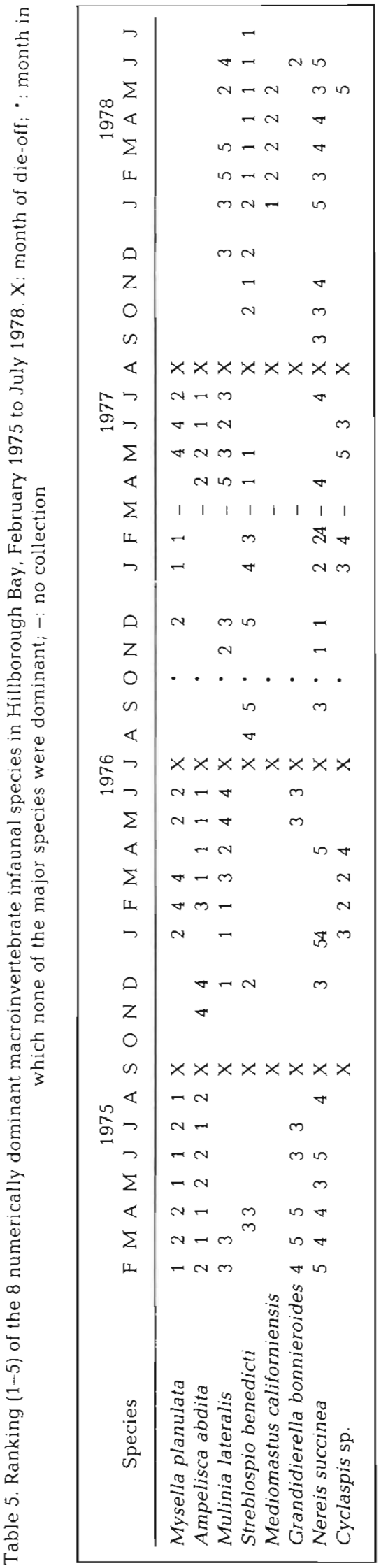


one would expect the taxa to display life-history strategies tending toward $r$-selection (Grassle and Grassle, 1974; McCall, 1977). Briefly stated, $r$-selected species are opportunistic, whereas $K$-selected species are equilibrium species (for a more detailed view of these ideas, see MacArthur and Wilson, 1967: Pianka, $1970,1974)$. Of the 80 taxa present at sometime during the study, the top ranked 8 (core) species, comprising $>95 \%$ of the total density, have been classified by various authors (Grassle and Grassle, 1974; McCall, 1977; Rhoads et al., 1978) as $r$-selected. The remainder (72 taxa accounting for $<5 \%$ of the density) may be divided into 2 groups, those occurring $10 \%$ or less of the time and those occurring more than $10 \%$ of the time. The first group may be considered as accidently occurring and are eliminated from further discussion. Of the remaining 33 taxa, occurrences at sampling periods vary, and although they may numerically dominate at some sampling periods (e.g. Oct. 1976, Table 5) densities are extremely low $\left(<66 \mathrm{~m}^{-2}\right)$. The locations of most of these taxa on the $r$ - $K$ continuum are unknown. Some of these taxa are capable of initially recolonizing the defaunated sediment (Santos and Simon in press) but are unable to attain high densities. Rhoads et al. (1978) suggest that although equilibrium species are capable of initial recolonization of marine soft-bottom environments, they cannot attain high densities until a 'microbial' garden has developed on the sediment particles. We do not feel that this is responsible in the present study because bacteria are present in the sediment throughout a cycle (L. Buckman, personal communication).

In the studies by Rosenberg (1972, 1973), Grassle and Grassle (1974), McCall (1977) and Rhoads et al. (1978), as colonization proceeded, the density of opportunistic species decreased while the density of equilibrium species increased. A decrease of $r$-selected species densities and increase of $K$-selected species densities did not occur in the present study. The 8 above-mentioned core species never relinquished their 'hold' on density dominance. As the above-cited studies were performed in areas that did not undergo periodic natural defaunations, environmental pressures and conditions are most likely different from Hillsborough Bay. Wolff et al. (1977), studying recolonization in a shallow embayment of the North Sea, also did not observe a shift from $r$ - to $K$-selected species density dominance. They attribute this lack to severe winter storms, which cause local defaunations in the bay creating empty patches, allowing the $r$ selected species to persist.

In the present study, the basic response of the organisms to the newly available habitat is repopulation by many species (15-29) with 1-6 species dominant at different times during the cycle. Organisms which are able to attain high densities rapidly ( $r$-selected species) are usually adapted for (1) some type of brood protection and (2) good dispersal abilities as larvae, juveniles or adults. Of the core group, the only species that have not been observed brooding young are Nereis succinea and Mulinia lateralis (personal observation). All, except Mysella planulata, from the study also appear to have a pelagic dispersal mechanism either as adults or larvae. This observation is in contrast to the findings of Franz (1973) and Ockelmann and Muus (1978). They found that $M$. planulata from Long Island Sound (Franz, 1973) and M. bidentata from the northern Oresund (Ockelmann and Muus, 1978) brooded their young only to the veliger stage. These were then released into the water column and assumed a planktotrophic development. $M$. planulata from the present study were observed releasing fully developed juveniles. $M$. sovaliki from Alaska has also been reported to brood juveniles until they are ready to assume a benthic existence (Ockelmann and Muus, 1978). Some species of spionid and cirratulid polychaetes (George, 1967; Simon, 1968; Woodwick, 1977) have been observed to produce two types of larvae, free-swimming for long range dispersal and benthic for local dispersal. Whether Mysella or any other species from this study is capable of this behavior is unknown. If the $M$. planulata from the present study did not produce a pelagic larval stage, this could account for the longer recovery period of this species. Ampelisca, on the other hand, has both an adult and juvenile pelagic dispersal mechanism and broods its young. Because of its tendency to migrate and settle en masse (Mills, 1967), it could rapidly attain high densities. The early maturation of Streblospio larvae, their brooding behavior and their ability to disperse pelagically as late stage larvae most likely is responsible for their success. Grandidierella and Cyclaspis follow the same strategy as Ampelisca. Nereis is capable of both adult and larval pelagic dispersion while Mulinia has only a larval type. Egg masses of Mediomastus have been observed in their tubes but not enough of their biology has been observed to allow supposition.

In the present study, not all core species were present each year, and of those that were, densities fluctuated widely. The two dominant species during the first two cycles, Ampelisca and Mysella, either did not appear during the third $(1977-78)$ cycle or appeared in such reduced numbers that a ranking in the top five was never attained. Streblospio, which prior to the 1977 die-off had been present at low densities at scattered intervals, became dominant for the entire 1977-78 cycle. Simultaneous to this, Mediomastus, which had been absent, appeared and attained very high densities. 
The loss of Ampelisca after the 1977 die-off is unexplainable. The rapid increase of Streblospio and Mediomastus, however, may be related to the disappearance of Ampelisca. Although no experimental data verify this possibility, circumstantial evidence is strong enough to allow speculation. Strebiospio is a small (5-15 $\mathrm{mm}$ long, $1 \mathrm{~mm}$ wide) tube-building polychaete that resides in the upper $1-2 \mathrm{~cm}$ of the substratum. If its densities are high, mats are produced on the surface. In some cases, one of us (SLS) has lifted the entire mat from the sediment similar to a piece of sod. The composition of the mat is such that it soon breaks apart. Ampelisca is also a tube-builder, constructing a larger tube extending deeper into the sediment. Ampelisca lie on their backs and feed by thrashing the antennae across the sediment-water interface, causing detritus to be suspended (Mills, 1967). They then filter the detritus from the water. Ampelisca also periodically vacate their tubes and swim en masse in the water column (Mills, 1967). Later they settle, build tubes and resume feeding. Possibly Ampelisca limits Streblospio populations in two ways. First, if Streblospio already are established, the settlement, tube-building and feeding behavior of Ampelisca would disrupt the Streblospio tubes. Secondly, once Ampelisca is established, feeding behavior would prevent successful recruitment of juvenile Streblospio (and perhaps other species as well).

Once the conditions which caused the defaunation abate, recolonization proceeds rapidly. Regardless of whether the initial recolonization is by members of the core group or any of the other taxa, the subsequent colonization sequence appears stochastic (Santos, 1979). However, due to the dispersal and brooding behavior, once all or some of the core species become established, they numerically dominate until the next defaunation. The conditions which allow the $r$-selected species to numerically dominate throughout the year, even in the presence of species that are probably more $K$-selected are unknown. One of the proposed hallmarks of being a good opportunistic species is a lack of competitive ability (Pianka, 1974), yet as suggested by Ampelisca, this may be an overgeneralization. In fact, Ampelisca may be a very effective interference competitor.

\section{APPENDIX}

Species present during study period (' denotes present at only one sampling period):

\section{Cnidaria}

- Paranthus rapiformis LeSueur 1817

Edwardsia sp.

Platyhelminthes

Stylochus sp.

\section{Rhynchocoela}

unidentified rhynchocoels

Polychaeta

Sthenelais boa (Johnston 1839)

Eteone heteropoda Hartman 1951

- Eumida sanguinea (Oersted 1853)

Phyllodoce arenae Webster 1879

Gyptis vittata Webster and Benedict 1887

Parahesione luteola (Webster 1880)

- Brania wellfleetensis Pettibone 1956

Nereis succinea Frey and Leuckhart 1847

Stenoninereis martini Wesenburg-Lund 1958

Glycera americana Leidy 1855

Glycinde solitaria (Webster 1879)

Diopatra cuprea (Bosc 1802)

Schistomeringos rudolphi (Delle Chiaje 1828)

Minuspio cirrifera (Wiren 1883)

Paraprionospio pinnata (Ehlers 1901)

Polydora ligni Webster 1879

Polydora socialis (Schmarda 1961)

- Polydora websteri Hartman 1943

Pseudopolydora sp.

Streblospio benedicti Webster 1879

- Tharyx sp.

Capitella capitata (Fabricius 1780)

- Capitellides jonesi Hartman 1959

Heteromastus filiformis (Claparede 1864)

Mediomastus californiensis Hartman 1944

Pectinaria gouldii (Verrill 1873)

Melinna maculata Webster 1879

Oligochaeta

unidentified oligochaetes

Pelcypoda

Amygdalum papyria (Conrad 1846)

Anadara transversa (Say 1822)

- Cyrtopleura costata Linnaeus 1758

Mulinia lateralis (Say 1822)

Corbula caribaea Orbigny 1842

Sphenia antillensis Dall and Simpson 1901

- Periploma margaritaceum (Lamarck 1801)

Mysella planulata (Stimpson 1851)

Semele proficua (Pulteney 1767)

Macoma tenta (Say 1834)

Tellina versicolor DeKay 1843

- Mercenaria campechiensis (Gmelin 1791)

Gastropoda

unidentified gastropod

Cochliolepis sp.

- Anachis obesa (C. B. Adams 1845)

Marginella apicina Menke 1828

Acteocina canaliculata (Say 1822)

Acteon punctostriatus (C. B. Adams 1840)

- Haminoea succinea (Conrad 1846)

Odostomia sp.

Turbonilla sp. 
Amphipoda

Ampelisca abdita Mills 1964

- Ampelisca verrilli Mills 1967

- Gitanopsis sp.

Grandidierella bonnieroides Stephenson 1949

- Rudilemboides naglei Bousfield 1973

- Cerapus tubularis Say 1818

Corophium tuberculatum Shoemaker 1934

Erichthonius brasiliensis (Dana 1853)

Gammarus mucronatus Say 1818

- Hyale sp.

Melita nitida Smith 1873

- Paraphoxus spinosus Holmes 1905

Parametopella cypris (Holmes 1905)

Isopoda

Erichsonella filiformis (Say 1818)

Munna reynoldsi Frankenberg and Menzies

Mysidacea

- Bowmaniella brasiliensis Bacescu 1968

Mysidopsis almyra Bowman 1964

Mysidopsis bigelowi Tattersall 1926

Cumacea

Cyclaspis sp.

Oxyurostylis smithi Calman 1912

Decapoda

Upogebia affinis (Say 1818)

Neopanope texana texana (Stimpson 1859)

Panopeus herbstii $\mathrm{H}$. Milne Edwards 1834

unidentified pinnotherid

Pinnixa sayana Stimpson 1860

Phoronida

Phoronis architecta Andrews 1890

Cephalochordata

* Branchiostoma caribaeum Sundevall

Acknowledgements. We would like to thank D. Carpenter, E. Pinson, C. Stiles-Lewis, J. Murdoch, F. Reeves, R. Mattson, and R. Kittrell for assistance with the SCUBA diving and other field work. Dr. S. A. Bloom provided the computer programs. $R$. Wilkens supplied the environmental parameter values. $K$ Mooren assisted in all aspects of this study. Dr R. W. Virnstein critically reviewed an earlier draft of this manuscript. Support for writing was provided by a postdoctoral fellowship (SLS) from Harbor Branch Institution. This research was partially funded by Florida Sea Grant R/EM-7 awarded to JLS.

\section{LITERATURE CITED}

Bagge, P. (1969). Effects of pollution on estuarine ecosystems. II. The succession of the bottom fauna communities in polluted estuarine habitats in the Baltic-Skagerak region. Merentutkimuslait. Julk./Havsforskningsınst. Skr. No. 228: $119-130$

Bloom, S. A., Santos, S. L., Field, J. G. (1977). A package of computer programs for benthic community analyses. Bull. mar. Sci. 27: 577-580
Brunswig, D., Arntz, W E., Rumohr, H. (1976). A tentative field experiment on population dynamics of macrobenthos in the western Baltic. Kieler Meeresforsch. 3: 49-59

Byers, S., Mills, E. L., Stewart, P. L. (1978). A comparison of methods of determining organic carbon in marine sediments with suggestions for a standard method. Hydrobiologia 58: $43-47$

Conner, W. G. (1977). Response of a soft-bottom ecosystem to physical perturbation. Ph. D. thesis, University of South Florida, Tampa, Florida

Crisp, D. J. (1971). Energy flow measurements. In: Holme, N A., McIntyre, A. D. (eds) Methods for the study of marine benthos. Blackwell, London, pp. 197-279

Dauer, D. M., Simon, J. L. (1976). Repopulation of the polychaete fauna of an intertidal habitat following natural defaunation: Species equilibrium. Oecologia 22: 99-117

Franz, D. R. (1973). The ecology and reproduction of a marine bivalve, Mysella planulata (Erycinacea). Biol. Bull. mar. biol. Lab., Woods Hole 144: 93-106

George, J. D. (1967). Cryptic polymorphism in the cirratulid Cirriformia tentaculata. J. mar biol. Ass. U.K. 47: 75-79

Grassle, J. F., Grassle, J. P. (1974). Opportunistic Iifehistories and genetic systems in marine benthic polychaetes. J. mar. Res. 32: 253-284

Gray, J. S. (1977). The stability of benthic ecosystems. Helgoländer wiss. Meeresunters. 30: 427-444

Holland, A. F., Mountford, N. K., Mihursky, J. A. (1977). Temporal variation in upper bay mesohaline benthic communities: 1 . The 9-m habitat. Chesapeake Sci. 18: 37-378

Holme, N. A. (1953). The biomass of the bottom fauna in the English Channel off Plymouth. J. mar. biol. Ass. U.K. 32: $1-49$

Inman, D. L. (1952). Measures for describing the size distributions of sediments. J. Sed. Petrol. 22: 125-145

Krumbein, W C. (1936). Application of logarithmic moments to size frequency distributions of sediments. J. Sed. Petrol. 6: $35-47$

Leppakowski. E. (1969). Transitory return of the benthic fauna of the Bornhoim Basin after extermination by oxygen insufficiency. Cah. Biol. Mar. 10: 163-172

MacArthur, R. H., Wilson, E. O. (1967). The theory of island biogeography. Monographs in population biology, No. 1. Princeton University Press, Princeton

Mason, W. R, Jr., Yevich, P. P. (1967). The use of phloxine B and rose bengal stains to facilitate sorting benthic samples. Trans. Amer Micros. Soc. 86: 221-223

McCall. P. L. (1977). Community patterns and adaptive strategies of the infaunal benthos of Long Island Sound. $J$ mar Res. 35: 221-266

McKay, C. F., Hartzband, D. J. \{1970\}. Propylene phenoxytol: narcotic agent for unsorted benthic invertebrates. Trans. Amer. Micros. Soc. 89: 53-54

Mills, E. L. (1967). The biology of an ampeliscid amphipod crustacean sibling species pair. J. Fish. Res. Bd Can. 24: 305-355

Ockelmann, K. W., Muus, K. (1978). The biology, ecology and behaviour of the bivalve Mysella bidentata (Montagu). Ophelia 17: 1-93

Paine, R. T (1971). The measurement and application of the calorie to ecological problems. Ann. Rev. Ecol. Syst. 2: $145-164$

Pearson, T H. (1975). The benthic ecology of Loch Linnhe and Loch Eli, a sea-loch system on the west coast of Scotland. IV Changes in the benthic fauna attributable to organic enrichment. J exp. mar. Biol. Ecol. 20,1-41

Pearson, T. H., Rosenberg, R. (1978). Macrobenthic succession in relation to organic enrichment and pollution of the 
marine environment. Oceanogr. Mar. Biol. Ann. Rev. 16: 229-311

Peterson, C. H. (1975). Stability of species and of community for the benthos of two lagoons. Ecology 56: 958-965

Pianka, E. R. (1970). On r- and K-selection. Am. Nat. 104: $592-597$

Planka, E. R. (1974). Evolutionary ecology, Harper and Row, New York

Rhoads, D. C., McCall, P. L., Yingst, J. Y (1978). Disturbance and production on the estuarine seafloor Am. Sci, 66: $477-486$

Rosenberg, R. (1972). Benthic faunal recovery in a Swedish fjord following the closure of a sulphite pulp mill. Oikos 23: $92-108$

Rosenberg, R. (1973). Succession in benthic macrofauna in a Swedish fjord subsequent to the closure of a sulphite pulp mill. Oikos 24: 244-258

Rosenberg, R. (1974). Spatial dispersion of an estuarine benthic faunal community. J. exp. mar Biol. Ecol. 16: $69-80$

Rosenberg, R. (1976). Benthic faunal dynamics during succession following pollution abatement in a Swedish estuary. Oikos $27 \cdot 414-427$

Rosenberg. R. (1977). Benthic macrofaunal dynamics, production and dispersion in an oxygen deficient estuary of west Sweden. J. exp. mar. Biol. Ecol. 26: 107-133

Sanders, H. L. (1958). Benthic studies in Buzzards Bay. I. Animal-sediment relationships. Limnol. Oceanogr 3: $245-258$
Sanders, H. L. (1969). Benthic marine diversity and the stability-time hypothesis. Brookhaven Symposium in Biology 22: $71-81$

Santos, S. L. (1979). Cyclic disturbance, recolonization and stability in a soft-bottom macrobenthic infaunal community. Ph. D. thesis, University of South Florida, Tampa, Florida

Santos, S. L., Simon, J. L. (1980). Marine soft-bottom community establishment following annual defaunation: Larval or adult recruitment? Mar Ecol. Prog. Ser 2: 235-241

Simon, J. L. (1968). Occurrence of pelagic larvae in Spio setosa Verrill 1873 (Polychaeta: Spionidae). Biol. Bull. mar biol. Lab., Woods Hole 134: 503-515

Simon, J. L., Dauer, D. M. (1977). Reestablishment of a benthic community following natural defaunation. In: Coull, B. C. (ed.) Ecology of marine benthos. University of South Carolina Press, Columbia, pp. 139-154

Tenore, K. R. (1972). Macrobenthos of the Pamlico River estuary, North Carolina. Ecol. Monogr, 42: 51-69

Watling, L. (1975). Analysis of structural variations in a shallow estuarine deposit-feeding community. J. exp. mar. Biol. Ecol. 19: 275-313

Wolff, W. J., Sandee, A. J. J., de Wolf, L. (1977). The development of a benthic ecosystem. Hydrobiologia 52: 107-115

Woodwick, K. H. (1977). Lecitrophic larval development in Boccardia proboscidae Hartman. In: Reish, D. J., Fauchald, K. (eds) Essays on polychaetous annelids in memory of Dr Olga Hartmann. Allan Hancock Foundation, Los Angeles, pp. 347-371 